\title{
Guided Training Model Development as an Improvement Strategy for Early Childhood Education Teachers' Assessment Ability
}

\author{
Sofia Hartati, Ade Dwi Utami, Lara Fridani \\ Universitas Negeri Jakarta, Jakarta, Indonesia \\ Corresponding e-mail: ade.dwi.utami@gmail.com
}

\begin{abstract}
This research aimed to develop a guided training model as an improvement strategy for early childhood education teachers' assessment ability in assessing children's development through learning activities to establish indicators of assessment ability for early childhood education teachers. Literature review has been done concerning teachers' assessment ability that comprises teachers' understanding in assessment, determining assessment type, using tools and procedure, conducting assessment process, using assessment result information, and obtaining data of training model used in teacher training. The data collection technique is conducted through observation, interview, Focus Group Discussion, and documentation analysis about the current training model used for teacher training in DKI Jakarta. The result of the research conducted is indicators for early childhood education teachers' assessment ability. The indicators show that specific knowledge and skill are required for assessment ability. On the other hand, there are two types of common training model used in teacher training namely guided and independent training. The condition should become a consideration of the education institution of educators, researcher and government in developing training model to improve teacher's pedagogic competence, including assessment ability.
\end{abstract}

Keywords: Assessment, Early Childhood Education, Training, Teachers.

\section{INTRODUCTION}

Education plays important role in the personal development of each individual. The quality of education could affect the quality on the individual learners, which includes early childhood education setting. It will have an impact to the progress of the country because the children will be the successor generation of the country. Therefore, children need excellence education service through the hands of teachers or educators

Early childhood teachers have significant role in achieving quality education. The Government Regulation No.19 of 2005 on National Education Standards states four competencies that must be understood, those are; pedagogical competence, personal competence, social competence, and professional competence. Pedagogical competence is one of the competencies that must be learned by teachers, because it can improve the quality of learning. One of the competencies required by the government is the assessment ability. Competence becomes a supportive factor for teachers in mastering the learning environment. However, in the reality, the teachers' assessment ability is questioned. It can be seen from the research conducted by Novianti, Puspitasari and Chairilsyah which illustrated some weaknesses in terms of knowledge and implementation of assessment by educators and early childhood institutions. Consequently, it required support from the government to improve teachers' assessment ability.

This research tried to figure out and evaluate early childhood teachers assessment ability in DKI Jakarta. The ability of assessment can be seen from five aspects those are determining the assessment tool based on developmental aspects, conducting observations, analysing observations, reporting the achievement of children's development, applying the results of the data into consideration design programs. This study is designed to obtain data 
about the teachers' assessment ability in early childhood education's institutions located in Jakarta.

\section{RESEARCH OBJECTIVES}

The purpose of this study is to explore early childhood teacher's assessment ability in DKI Jakarta towards the children. In particular, this study aims to

a. Describe teachers' understanding towards assessment principle

b. Describe the assessment procedure conducted by teacher

c. Describe the assessment process conducted by the teacher.

d. Describe the use of information in assessment's result.

\section{LITERATURE REVIEW}

\subsection{Pedagogic Competence}

Competence must be applied to improve the quality of each individual. Katane explains that competencies are defined as "the set of knowledge, skill, and, experience necessary for future, which manifests in activities". This knowledge, skills and experience should be applied in daily life.

The Indonesian Government has set four competencies required by teachers. It is based on the Government Law No.14 of 2005 on Teachers and Lecturers, Chapter IV, Article 10, paragraph 1, which stated that the competencies that must be preserved by a teacher, among others; a) personal competence, b) pedagogic competence, c) professional competence, and d) social competence. Teachers are required to do their personal role. Therefore teachers are required to apply the four competencies in their daily life. The application of the competency of teachers will affect the professionalism of teachers as educators.

Pedagogical competence becomes competencies that differentiate the teaching profession to other professions. The government regulation No.19 of 2005 states that teachers' pedagogical competence is the ability to manage students learning, designing, and implementing the learning process, as well as to evaluate the learning outcomes and development of students with various potency.
Practice becomes the most important word in the definition of pedagogical competence. Apelgren \& Giertz (2013: 3) states that; "pedagogical competence is not enough to have knowledge and skills that are needed. This is because the most important word in the definition is practice. It is emphasized that pedagogical competence means that the teacher also uses his/her knowledge and applies acquired insights and skill". Pedagogical competence is the ability influenced only by an educator in charge of learning management, learning design, and evaluation of learning outcomes that are appropriate to children's development and applied as a reference in managing learning to enhance the potential that exists in the children's personal life. Pedagogical competence is the key factor in determining the quality of the learning process.

Pedagogical competence has an important role in improving the quality of the learning process. Apelgren \& Giertz (2013: 3) say "pedagogical competence as the ability and will to regularly apply the attitude, the knowledge, and the skill that promote the learning of the teacher's students in the best way". Teachers can increase the potential of children with pedagogical competence possessed. Pedagogical competence can enhance the professionalism of teachers as educators, it brings effect to the performance of teachers, advance the quality of teachers, and improve pedagogical competence. Pedagogical competence have an important role in managing the teaching and learning program in order to actualize the potential of children which support and learning facilities. That role can determine the quality of learning that will be received by the child.

Teacher's competency is one of the factors in developing the professionalism of teachers as an educator. European Commision (2012:11) said that Conceptualisations of teacher competence are linked with the visions of professionalism, theories of teaching and learning, quality cultures, and sociocultural perspective. Competency of teachers can not be separated from professionalism.

The Australian Institute for Teacher and School Leadership (AITSL) (2011: 5) define the seven standards for teachers' professionalism as follow: 
Table 1. AITSL standards for teachers' professionalism

\begin{tabular}{ccl}
\hline $\begin{array}{c}\text { Domains of } \\
\text { Teaching }\end{array}$ & \multicolumn{1}{c}{ Standard } \\
\hline $\begin{array}{c}\text { Professional } \\
\text { Knowledge }\end{array}$ & 2. & $\begin{array}{l}\text { Know the students and how } \\
\text { they learn } \\
\text { Know the content and how to } \\
\text { teach it }\end{array}$ \\
\hline 3. & $\begin{array}{l}\text { Plan for and implement } \\
\text { effective teaching and } \\
\text { learning }\end{array}$ \\
Practice & 4. & $\begin{array}{l}\text { Create and maintain } \\
\text { supportive and safe learning } \\
\text { environment. } \\
\text { Assess, provide feedback and } \\
\text { report on student learning }\end{array}$ \\
\hline $\begin{array}{l}\text { Professional } \\
\text { Engagement }\end{array}$ & 7. & $\begin{array}{l}\text { Engage in professional } \\
\text { learning } \\
\text { Engage professionally with } \\
\text { colleagues, parent/carers } \\
\text { and the community }\end{array}$ \\
\hline
\end{tabular}

One of the standards in professional practice is the assessment, which provide feedback and student learning report. Based on those standards, teachers are expected to be able to evaluate the children's development and learning outcomes. It can facilitate teachers in identifying children's learning needs. In addition, teachers can also find out the limitations of the children learning program so that teachers can provide service for children better.

As a standard for global reference in maintaining the quality of early childhood education, especially in the learning process, NAEYC (2009: 13) states professional standards for early childhood education, specifically "1) Promoting child development and learning, 2) Building Family and Community Relationships, 3) Observing, Documenting, and assessing to support young children and families, 4) using developmentally effective approaches 5) using content knowledge to build meaningful curriculum, 6) becoming a professional". Improved education quality and excellence can be detected by observing, documenting, and implementing assessment through a variety of approaches and tools as applicable.

Observation, documentation and assessment are standards which is established by NAEYC. NAEYC suggests that three key elements or components of the observation, documentation and assessment which stated "1) understanding the goals, benefit, and uses of assessment, 2) knowing about and using observation, documentation and other appropriate assessment tools and approaches, 3) understanding and practicing responsible assessment to promoting positive outcomes for each child 4) knowing about assessment partnerships with families and with professional colleagues".

Assessment generally used to be able to see children development. Therefore, it helps to achieve learning goals specifically, and to plan and implement the curriculum effectively. This must be accompanied to consider the results of the assessment.

The teachers' assessment ability to assess children's learning process and results are described in The Ministry of Education's regulation No.137 in 2014 specifically; 1) the principles of assessment, 2) Instrument assessment, 3) assessment mechanisms, 4) the implementation of the assessment and 5) reporting the results of the assessment. Assessment which completed will illustrate the achievement of child development and the process through the implementation of the assessment.

\subsection{Teachers' Assessment Ability}

Assessment is a process which is designed to complement the activities with the achievement of the children's development. Deborah states that "assessment is the basic process of finding out what we know and what we can do in relation to children's optimum development and the goals of the program. By having information about the children. Teacher can plan an appropriate curriculum and an effective instructional strategies to help children develop and learn, and monitoring their progress along the way". By conducting an assessment, teacher can observe and know the children's chart progress in learning activities.

The process of children development can be seen through various children's activity in various way. Flottman, Stewart and Tayler (2011: 6) states that "assessment is designed to discover what children know and understand, based on what they make, write, draw, say, and do". Teachers could see the development as the ability of what children create, write, draw and do. The assessment ability is considered as the capacity of teachers in the process of gathering information about the growth and development that is conducted periodically, continuously, and comprehensively in a learning process of what children create, write, draw, say and do.

Assessment has some principles as guidelines for the implementation in the field. Shepard, Kagan, and Wurtz (2000: 5) summarize the principles of early childhood assessment in the Principles and Recommendation for Early Childhood Assessments. It is stated that "the following general principle should guide both policies and practices for the assessment of young children; 1) should bring about benefits for children, 2) be tailored to a specific purpose and should be realible, valid, and fair for 
that purpose, 3) be designed recognizing that reliablitiy and validity of assessments increase with children's age, 4) be age-appropriate in both content and the method of data collection, 5) be linguistically appropriate, recognizing that to some extent all assessment are measures of language, 6) be a valued source of assessment information, as well as an audience for assessment results". The six principles can assist teachers in the implementation of assessment, the results can be sufficiently achieved. Therefore, teachers must master the principles of assessment in detecting completion of a child's development.

Implementation of assessment should in line with the principles which have been created. Wotham in Demircan (2011: 16) outlines some principles assessment in early childhood education 1) use many sources of information and learning measures, 2) improve learning, 3) Fairness, 4) involve both the child and his/her family. Some of these principles could monitor children development optimally.

The principle of assessment is needed in order to draft an impact on the learning process of children development. Yus $(2011 ; 56)$ presented seven principles of assessment for the development of kindergarten children. 1) Systematically, 2) continuous, 3) processes and goals oriented, 4) objectives, 5) educate, 6) significance, 7) appropriateness. The seven principles facilitate and guide teachers in implementing the assessment in early childhood.

The implementation of assessment requires teachers to be able to focus on the aspects that will be seen in describing the child's development. Helm (2011: 2) states that "assessment is tools or process for answering specific question about various aspect of children's knowledge, skill, behaviour, or personality". Teacher can do that by observing and collecting data on the knowledge, skills and behaviour. So the results of observation and data collection can be adapted to the achievement of the children's development.

The identification of aspects considered as the significant step in making the assessment. Snow (2011: 14) says "assessments provide means of evaluating individuals' skills, abilities, or traits". From these statements it can be seen that the skills, abilities and characteristics of individual children are three aspects that will be develop through the implementation of the assessment.

Assessment for early childhood is a collecting information about the children. Therefore, teachers need to be able to focus on aspects of the collection of such information. Anon (2008: 11) ".....that we assess young children's behaviours, skills, competencies, preferences, and interaction". Data collection is aimed to improve the understanding of children development and support of learning and development. Target assessment will be conducted in children include six dimensions of development: physical, cognitive, language, art, social-emotional, motor and religious values. Thus the teacher can give to his focus on the development of the six dimensions. Assessment has aspects as focus in collecting information related to the perceptive and support of learning and development. The aspect consists of the skills, abilities, behaviours, and trends in a variety of potential children. The fourth aspect is seen from the sixth dimension that includes the development of physical, cognitive, language, art, social-emotional, motorized and religious values. Teachers can see the skills, abilities, behaviours, and children growing in the six dimensions.

Assessment procedures as the implementation process in order to illustrate the development of the real child. Here are the description of assessment process that has been set by the ELS (Early Learning Scale) (2010: 7).



Figure 1. The assessment process

The data can be used by teacher to determine the needs' targets of each child, so that teachers can provide instruction in the form of activities in accordance with what they need. Once teachers obtain data related to the achievement of development of the child, the teacher can design a variety of activities to improve children's development.

Achievement of children's development can be determined by performing an assessment in accordance with existing procedures. Yus $(2011 ; 56)$ identified the procedure for the implementation of kindergarten children learning development: 1) define the activities, 2) prepare an assessment tool, 3) establish assessment criteria, 4) collect data, 5) determine the value. Through these procedures, the 
teacher can implement assessment in compliance with the principles of assessment. So that teachers can view and monitor the process of children's development.

Another opinion related to the implementation of the assessment process described by Wortham. Wortham (2005: 32) explains that the process of implementation of assessment for early childhood, namely; 1) assessment at beginning of the year: preassessment, 2) ongoing asesment, 3) assessment at the end of reporting periods, 4) assessment at the end of the school year. The assessment process should be considered and implemented to determine the cadence and rhythm of development. Thus teachers can use that data in determining the target achievement and learning objectives.

The assessment results have an impact on improving early childhood learning processes. Helm (2011: 2) which states "assessment result can identify both the well-developed and least welldeveloped skill of children so that beneficial learning experiences and teaching can be individually planned and carried out". The assessment results can be used for the development of further activities in accordance with the needs of children.

The benefit from the results of the assessment in the program of activities submitted Snow, Susan and Hewel (2011: 43). They state that "The result of such assessment would be used to refine the program practices with the expectation that the outcomes for children would improve even further. The results of the assessment, the children will get treatment to improve the graphics developments.

Teachers analyze data on the achievement of the child's development in stages. Yus $(2011 ; 106)$ assume the results of the analysis of the information on the achievement of growth and development of children within a certain time, for example a week, a month or a semester and so on. In this way, teacher will receive assessment results that illustrate the development of children in each week, month or semester. Early childhood assessment results can be used to identify the skills and knowledge regularly. Therefore, the children's development chart will describe at each week, month or semester. Through the identification result, teachers can create and improve learning programs so that what is given can be useful and meaningful.

\subsection{Basic of Teachers}

Teachers' profession become a need in the world of education. In Indonesian regulation No.14 year
2005, Chapter I, Article 1 in Paragraph 1 of Teachers and Lecturers, it stated that teachers are professional educators with the primary task of educating, teaching, guiding, directing, train, assess, and evaluate students on early childhood education, formal education, basic education, and secondary education.

Teachers are the key of success in the learning process. Deborah (2010: 497) argues "That teachers are keys to student learning, and efforts to improve teacher quality have proliferated". Teacher is an educator who became a key element in the passage of the learning process. That is because teacher has a learning strategy in explaining the purpose of the material to be delivered. Therefore, teachers are required to improve the competence to continue to learn and to do their job in educating, teaching, guiding, directing, train, assess, and evaluate to provide motivation for learners through the levels of education, including early childhood education institutions.

The government regulation No.14 in 2005 chapter I, Article 1, Paragraph 1 of Teachers and Lecturers stated that teachers are professional educators with the primary task of educating, teaching, guiding, directing, train, assess, and evaluate students on early childhood education, formal education, basic education, and secondary education. The main task is to make the teacher as a determinant of the quality of the nation's future.

Teachers perform as a central figure in achieving educational objectives. Possessed a significant role requires teachers to prioritize competence as a capital increase in performing its main task. Self-awareness to continue to improve the competence of teachers is the key factor in educating the young generation.

\subsection{Training}

Planning allows for the smooth implementation of the educators' tasks. According to Wexley \& Latham (1991), "training and development refers to planned effort by on organization to facilitate the learning of job-related behaviour on the part of its employees". Therefore, employment training and development plays a vital role in increasing the knowledge and skills of the policy implementers in conducting their tasks in order to achieve the organization's objectives.

According to William J.R, "training and development does not assess training needs systematically, does not try to demonstrate a financial return on investments, and does not 
distinguish training from management problems". Training and education are systematical activities which require demonstrations of knowledge and skills in order to deal with management problems.

Another expert, Lois B says, "Trainers always design workshops that will make such an impact on participants that they will retain and apply what was learned".

Training is a part of effort in developing human resource. Konopaske and Ivancevich state that training is the systematic process of altering the behaviour of employees in a direction that will achieve organizations goals. (Konopaske dan Ivancevich, 2013). This means that training is a systematic process to change individual behaviour to achieve the organization goal. A good organization needs a training for improving the quality of human resource involved. An organization can provide a training for the advancement of their human resource according to the needs in the field. Wexley and Latham state that training and development refers to a planned effort by an organization to facilitate the learning of job related behaviour on the parts of its employees. (Wexley and Latham, 1991). It means that training and development refer to a systematic effort of an organization to facilitate that the employee learning behaviour. An organization also can provide a training for their human resource according to their target.

\section{METHODOLOGY}

\subsection{Research Cohort}

Early Childhood Education teachers in DKI Jakarta. The population includes Jakarta consisting of five cities covering several districts that have early childhood education institutions either kindergarten or other early childhood institution in which have educators or teachers. Thus the researchers used samples from several districts in Jakarta.

\subsection{Research Tools}

The method conducted in this research is a mixed method with explanatory techniques. Creswell said that the sequential explanatory applied to the collection and analysis of quantitative data in the first stage followed by the collection and analysis of qualitative data in the second phase upon the preliminary results quantitatively. So that the results of the qualitative data processing is used to clarify the results of the quantitative data that has been obtained. Quantitative method used is survey method. Arikunto (2006: 309) states that a descriptive research is research that intended to collect information about the status of an existing symptoms, the symptoms according to what their circumstances at the time of the study. Information attained in describing the data as teacher assessment capabilities Early Childhood Education. This study focuses on the ability of the teacher assessment. It can be seen that the ability of the teacher assessment is one component of teacher capabilities that can support the quality of the learning process.

This research use a research and development method. Richey and Nelson identify that a developmental research is oriented to develop a product through a process of development which is described and evaluated in detail. (Richey dan Nelson, 1996). This research and development is aimed to develop a design training product, which start from teacher's case exploration in early childhood education institution around DKI Jakarta which theoretically can be the basis to develop guided training model development. Van den Akker calls this as a formative research that is a research activity which is conducted in a cycling process and is directed to the optimalization of quality implementation product in certain condition (Van den Akker, 1999). The result of exploring the cases which is conducted in the need assessment, is treated as the basis of managing research training design product. In this way, a good guided training model development can be created. This research development is conducted in cycling activities based on the design and examining the training activity which is followed by guided training in direct practice, discussion and consultation. The result of this research is a research product which is good in quality including methodology, theoretically and empirically.

\section{RESULTS AND DISCUSSION}

The results of the research in teacher assessment abilities are indicators were conducted of 8 aspects of assessment that determine the assessment ability to be used based on the teacher knowledge, teacher skill in implementing the knowledge. 
Table 2. Indicators Early Childhood Teachers' Assessment Ability

(Shepard, Kagan and Wurtz, 2000, Demircan, 2011, Deborah, Kennedy and Anne Stonehouse. 2012)

\begin{tabular}{|c|c|}
\hline $\begin{array}{c}\text { Assessment } \\
\text { Aspects }\end{array}$ & Indicators \\
\hline \multirow{3}{*}{ Concept } & $\begin{array}{l}\text { Teacher explain the objective of } \\
\text { assessment (comprehension) }\end{array}$ \\
\hline & $\begin{array}{l}\text { Teacher explain the benefit of } \\
\text { assessment (comprehension) }\end{array}$ \\
\hline & $\begin{array}{l}\text { Teacher use the result of assessment } \\
\text { (application) }\end{array}$ \\
\hline \multirow{3}{*}{$\begin{array}{l}\text { Determining } \\
\text { assessment } \\
\text { method }\end{array}$} & $\begin{array}{l}\text { Teacher determine the assessment } \\
\text { method according to child } \\
\text { characteristic (application) }\end{array}$ \\
\hline & $\begin{array}{l}\text { Teacher determine the assessment } \\
\text { method according to aspect of } \\
\text { development which assessed } \\
\text { (application) }\end{array}$ \\
\hline & $\begin{array}{l}\text { Teacher design the plan to do the } \\
\text { assessment (synthesis) }\end{array}$ \\
\hline \multirow{5}{*}{$\begin{array}{l}\text { Determining } \\
\text { assessment } \\
\text { tools }\end{array}$} & $\begin{array}{l}\text { Teacher determine the aspect of } \\
\text { development which want to be } \\
\text { assessed (application) }\end{array}$ \\
\hline & $\begin{array}{l}\text { Teacher identify the assessment tools } \\
\text { (application) }\end{array}$ \\
\hline & $\begin{array}{l}\text { Teacher create the assessment tools } \\
\text { according to child characteristic } \\
\text { (synthesis) }\end{array}$ \\
\hline & $\begin{array}{l}\text { Teacher choose the assessment tools } \\
\text { according to aspect of development } \\
\text { which assessed (application) }\end{array}$ \\
\hline & $\begin{array}{l}\text { Teacher choose the assessment tools } \\
\text { according to child characteristic } \\
\text { (application) }\end{array}$ \\
\hline \multirow{5}{*}{$\begin{array}{l}\text { Implementing } \\
\text { assessment }\end{array}$} & $\begin{array}{l}\text { Teacher explain the assessment } \\
\text { process (comprehension) }\end{array}$ \\
\hline & $\begin{array}{l}\text { Teachers are able to make a note or } \\
\text { recording for child's behaviour using } \\
\text { the assessment tools (synthesis) }\end{array}$ \\
\hline & $\begin{array}{l}\text { Teacher is able to use each assessment } \\
\text { tools (application) }\end{array}$ \\
\hline & $\begin{array}{l}\text { Teacher is able to combine the } \\
\text { assessment tools according to the } \\
\text { needs in implementing assessment } \\
\text { (synthesis) }\end{array}$ \\
\hline & $\begin{array}{l}\text { Teacher is able to separate the } \\
\text { subjective perspective in assessing } \\
\text { (analysis) }\end{array}$ \\
\hline
\end{tabular}

Table 2. Cont.

\begin{tabular}{|c|c|}
\hline \multirow{5}{*}{$\begin{array}{l}\text { Analysing the } \\
\text { assessment } \\
\text { result }\end{array}$} & $\begin{array}{l}\text { Teacher is able to identify child } \\
\text { knowledge (analysis) }\end{array}$ \\
\hline & $\begin{array}{l}\text { Teacher is able to identify child skill } \\
\text { (analysis) }\end{array}$ \\
\hline & $\begin{array}{l}\text { Teacher is able to identify child } \\
\text { behaviour (analysis) }\end{array}$ \\
\hline & $\begin{array}{l}\text { Teacher give a feed back to the } \\
\text { assessment result (synthesis) }\end{array}$ \\
\hline & $\begin{array}{l}\text { Teacher respect the individual } \\
\text { differences between the children } \\
\text { (evaluate) }\end{array}$ \\
\hline \multirow{3}{*}{$\begin{array}{l}\text { Reporting } \\
\text { child } \\
\text { development } \\
\text { achievement }\end{array}$} & $\begin{array}{l}\text { Teacher determine the component in } \\
\text { conducting the assessment report } \\
\text { (application) }\end{array}$ \\
\hline & $\begin{array}{l}\text { Teacher identify child development } \\
\text { issues (analysis) }\end{array}$ \\
\hline & $\begin{array}{l}\text { Teacher is able to summarize the child } \\
\text { development in certain range of time } \\
\text { (evaluate) }\end{array}$ \\
\hline $\begin{array}{l}\text { Evaluating the } \\
\text { assessment } \\
\text { process }\end{array}$ & $\begin{array}{l}\text { Teacher evaluate the assessment } \\
\text { process (evaluate) }\end{array}$ \\
\hline \multirow{2}{*}{$\begin{array}{l}\text { Using the } \\
\text { assessment } \\
\text { result as } \\
\text { consideration } \\
\text { to conduct } \\
\text { learning } \\
\text { program }\end{array}$} & $\begin{array}{l}\text { Teacher rearrange the learning target } \\
\text { (synthesis) }\end{array}$ \\
\hline & $\begin{array}{l}\text { Teacher design the learning program } \\
\text { to reach the learning target }\end{array}$ \\
\hline
\end{tabular}

The instrument was build according to the indicators of assessment ability. The instrument used in test form and observation form. The test form is consist of 11 questions for teacher and the observation consist of 18 statements to observed.

On the other hand, the model of training which is common for teacher training are guided training and independent training.

\section{CONCLUSION}

The general results of the study presented the indicators of the ability of early childhood teachers in assessment. These indicators are used for conducting instrument to assess teachers' knowledge and understanding in applying the assessment. This statement disrupted by qualitative results stating that the teacher does not specify what aspects will be assessed in the study, did not record a child's behaviour, and did not take advantage of the data results into consideration to design the program. Teachers have assessment documents, but those documents only as of form of teacher certification requirements. 


\section{SUGGESTION}

It is advisable for teachers to further expand their knowledge to get the importance of assessment in learning process. Information must be applied so that children learnt what is needed for their academic life. Further research can provide a program that can offer insight for teachers in applying the assessment; the government is expected to give awareness to describing the capabilities development program as a follow-up assessment of the condition of teachers in the field.

\section{REFERENCES}

AITSL, (2011). Australian Professional Standards for Teacher. Australian Jurnal of Teacher Education.

Apelgren Karin \& Olsson Thomas, (2010). A Swedish perspective on Pedagogical Competence. UPPSALA University.

Aziz Fakhra, Muhammad Mahar dan Akhtar Saeed, (2014). Impact Of Training On Teacher Competencies At Higher Education Level In Pakistan, Vol.-V, Issue-1, Jan 2014. International Refereed Research Journal.

Catherine E. Snow and Susan B. Van Hemel, (2008). Early Childhood Assessment: Why, What and How.The National Academies

Colin Marsh, (2008). Becoming A Teacher; Knowledge, skill and issues. Australia : PEARSON.

Deborah Loewenberg. B \& Francesca M.Forzani, (2009). The Work Of Teaching and The Challenge For Teacher Education. Journal of Teacher Education.

Deborah, McAfee, Oralie, et al., (2004). Basic Of Assessment : A primer For Early Childhood Educator. Washington : NAEYC.

European Commission, (2013). Supporting Teacher Competence Development for Better Learning Outcomes.

NAEYC, (2009). NAEYC Standard for Early Childhood Professional Preparation Program. NAEYC Governing Board July.

Nicholls, John G., (1989). The competitive Ethos and democratic education. USA, the President and Fellows of Harvard College.

Nielsen, (2006). The Teacher's Role. Nielsen Training Services, Inc.

Novianti, Ria DKK, (2013). Pemetaan Kemampuan Guru PAUD dalam melaksanakan Asesmen Perkembangan Anak Usia Dini di Kota Pekanbaru. Jurnal SOROT, Vol.8, No.1, April
2013 hal 1-104; Lembaga Penelitian Universitas Riau.

Olatunji, Michael Olalekan, (2013) Ensuring and Promoting The Pedagogical Competence of University Lecturers In Africa. Journal of educational and instructional studies in the world. vol.3, issue: 3 article. 